\title{
Performance of chlorothalonil levels and spraying intervals on Asian rust control and soybean grain yield
}

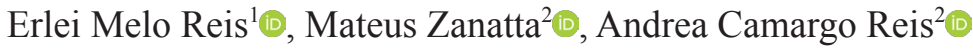

${ }^{1}$ Programa de Pós-graduação Universidade de Buenos Aires, Escuela de Pósgrado Alberto Soriano, Universidade de Buenos Aires, Av. San Martin, 4453, Buenos Aires, Argentina. ${ }^{2}$ Agroservice/Agroresearch Passo Fundo, Rua Miguel Vargas, 291, Passo Fundo, RS, Brasil. CEP 99025-380. Autor para correspondência: Erlei Melo Reis (erleireis@upf.br)

Data de chegada: 28/06/2018. Aceito para publicação em: 03/07/2019.

$10.1590 / 0100-5405 / 204867$

\section{ABSTRACT}

Reis, E.M.; Zanatta, M.; Reis, A.C. Performance of chlorothalonil levels and spraying intervals on Asian rust control and soybean grain yield. Summa Phytopathologica, v.45, n.3, p.261-264, 2019.

In an experiment conducted in the field, during the 2017/18 growing season, with the soybean cultivar Syn 1561 IPRO, the interaction of chlorothalonil levels with application intervals was evaluated for the control of Asian soybean rust, caused by Phakopsora pachyrhizi. The first fungicide application was performed in V8 stage, 44 days after emergence, with $1.85 \%$ rust leaflet incidence. The experiment consisted of a factorial arrangement with five fungicide levels $(1.0,1.5,2.0,2.5$ and $3.0 \mathrm{~L} / \mathrm{ha})$ applied at 8,12 and 16-day intervals, using randomized block treatments and four replicates. A selfpropelled sprayer with 16 bars, XR11001VS nozzles and $150 \mathrm{~L} / \mathrm{ha}$ volume was employed. Leaflet rust severity in R5.4 stage and grain yield were evaluated. Data were subjected to analysis of variance, and means were compared according to Tukey's test. At eight-day intervals (six sprayings), control ranged from $75 \%$ to $93 \%$; at 12 -day intervals (four sprayings), it ranged from 35 to $63 \%$, and at 16-day intervals (three sprayings), control ranged from 15 to $29 \%$ according to the sprayed levels. The longer the interval between applications, the lower the response of the used level for rust control and soybean grain yield. Chlorothalonil showed fungitoxicity to integrate a program of anti-resistance strategies to control soybean rust.

Keywords: chloronitrile, multisite fungicide Glycine max, Phakopsora pachyrhizi

\section{RESUMO}

Reis, E.M.; Zanatta, M.; Reis, A.C. Desempenho de doses e do intervalo de aplicações do clorotalonil no controle da ferrugem asiática e no rendimento de grãos da soja. Summa Phytopathologica, v.45, n.3, p.261-264, 2019.

Em experimento conduzido no campo, na safra 2017/18, com a cultivar Syn 1561 IPRO, avaliou-se a interação de doses e de intervalos entre aplicação do fungicida clorotalonil no controle da ferrugem asiática da soja, causada por Phakopsora pachyrhizi. A primeira aplicação do fungicida foi realizada no estádio V8, 44 dias após a emergência, com incidência foliolar da ferrugem de $1,85 \%$. O experimento constou de um esquema fatorial de cinco doses $(1,0$, $1,5,2,0,2,5$ e 3,0 L/ha) do fungicida aplicadas nos intervalos de 8,12 e 16 dias, em tratamentos distribuídos em blocos ao acaso com quatro repetições. Utilizou-se um pulverizador autopropulsado com 16 barras, pontas XR11001VS e volume de $150 \mathrm{~L} / \mathrm{ha}$. Avaliou-se a severidade foliolar da ferrugem no estádio R5.4 e o rendimento de grãos. Os dados foram submetidos a análise da variância e comparação de médias pelo teste de Tukey. Com intervalo de oito dias (6 aplicações) o controle variou de 75 a 93\%, com intervalos de 12 dias (4 aplicações) variou de $35 \%$ a $63 \%$ e com 16 dias ( 3 aplicações) variou de 15 a $29 \%$ em função das doses. Quanto maior o intervalo entre aplicações, menor foi a resposta de dose para o controle e para a produção de grãos. O clorotalonil tem fungitoxicidade para integrar um programa de estratégias anti-resistência no controle da ferrugem da soja.

Palavras-chave: cloronitrila, fungicida multissítio Glycine max, Phakopsora pachyrhizi.

Soybean [Glycine $\max (\mathrm{L}$.$) Merr.] grown area in Brazil has$ increased every season. As a result, in the 2017/18 growing season, 35.3 million hectares were cultivated in the country (1).

Several diseases have been reported for soybean, but Asian rust (ASR), caused by a species of the Phakopsoracea family, Phakopsora pachyrhizi $(P p)$ Sydow \& Sydow, and found in South America (Paraguay and Brazil) in the 2001/02 season by Morel (6), is the most destructive disease.

Damage caused by a plant disease is the basic tool to justify whether control is needed or not. It must be scientifically determined. For ASR, the damage can be estimated based on the functions reported by Danelli et al. (2).

ASR control measures include elimination of volunteer plants, observation of a 60-90-day soybean-free period in the off-season, cultivation of early cultivars sown at the beginning of the recommended season, and use of cultivars with partial resistance and chemical control (11). However, fungicides are still the main measure for its control.

The site-specific DMIs alone, flutriafol and tebuconazole, were the first fungicides used to control ASR. The reported reduction in $P p$ sensitivity to DMIs, after six seasons of use $(9,13)$, made double site-specific mixtures (DMIs + QoIs) replace them. Subsequently, from 2011/12 season, double mixtures (QoIs + SDHIs) were launched in the market and are used up to the present. In 2013/14 season, the first site-specific triple mixture (DMI+QoI+SDHI) was delivered to be used by farmers. Consequently, in the 2016/17 season, a new triple mixture was launched.

Since the beginning of fungicide use in ASR control, in 2002/03 season, there has been a constant reduction in $P p$ sensitivity towards 
the three modes of action of site-specific fungicides season after season.

The use of site-specific fungicides alone or in double mixtures in the entire cultivated area and with more than two sprayings/ha has resulted in reduced control efficacy, now lower than 50\% (9). In the 2017/18 season, no site-specific co-formulations showed control higher than $50 \%$, since control efficacy should be $>80 \%$ to be sustainable (10).

Reduced $P p$ sensitivity to site-specific fungicides has been shown in farms, field experiments and in the laboratory using detached soybean leaflets. Complementary studies have identified $P p$ mutations involved with cross-resistance among the three mechanisms of action: cyp 51 point mutations and overexpression to DMIs (12), F129L to QoIs (5), and I86F to SDHIs (14). Sensitivity reduction has been shown for fungicides alone or for any of their double or triple mixtures (9), thus resulting in $P p$ cross and multiple-resistance to the three site-specific MOA fungicides.

The main anti-resistance strategy of fungi to site-specific fungicides, as observed in the control of downy mildews in potato, tomato and grapevine crops, has been their mixture with multi-site chemicals such as chlorothalonil, copper oxychloride, mancozeb and tin compounds (9).

We hypothesized that chlorothalonil may have fungitoxicity against $P p$ and integrate treatment programs, added to the site-specific chemicals both in double or triple co-formulations as an anti-resistance strategy.

The objective of this study was to quantify the effects of the interactions between chlorothalonil levels and spraying intervals on ASR control and soybean grain yield.

\section{MATERIAL AND METHODS}

The study was conducted in Passo Fundo County, Rio Grande do Sul State, district of Bela Vista $\left(28^{\circ} 12^{\prime} 18\right.$ ' 'latitude, 52 $29^{\prime} 45^{\prime \prime}$ ' longitude and altitude 660 a.s.l.) with soybeans Syn 1561 IPRO, maturity group 5.9. Soybean was directly drilled on December $12^{\text {th }}, 2017$, in $2.5 \times 6.0$ $\mathrm{m}$ plots, in an area of soybean monoculture.

The fungicide chlorothalonil [IUPAC: 2, 4, 5, 6 tetrachloroisophthalonitrile (Syngenta, Bravonil ${ }^{\circledR} \mathbf{7 2 0}$ SC)] was tested in a factorial design involving five levels $(1.0,1.5,2.0,2.5$ and $3.0 \mathrm{~L} /$ ha commercial formulation) and three spraying intervals $(8,12$ and 16 days).

Fungicide spraying was performed by using self-propelled Sider ${ }^{\circledR}$ sprayer with multi-bars, Teejet ${ }^{\circledR}$ XR11001VS spraying nozzles, and $150 \mathrm{~L} /$ ha volume.

From V5 stage, 20 leaflets of the $5^{\text {th }}$ to $7^{\text {th }}$ nodes were weekly removed, taken to the laboratory and searched for the presence of rust symptoms/signs under a Zeiss stereomicroscope (20 - 50x magnifications). The first spraying was performed after rust detection in the experimental area and the remaining ones at 8,12, and 16-day intervals.

Rust severity was assessed according to the diagrammatic scale of Godoy et al. (3), and ASR control by the fungicide treatments was calculated in relation to the unsprayed plots.

Experimental design was factorial (five levels and three spraying intervals) in randomized blocks and four replicates. Severity data, rust control and grain yield were subjected to ANOVA and means were compared according to Tukey's test and regression analyses between grain yield and severity, yield and control, and control and damage.

At ripening, grains were harvested with an adapted plot combine (Massey Ferguson 220); then, grains were cleaned, humidity was adjusted to 13 , and grain yield was expressed as $\mathrm{kg} / \mathrm{ha}$.

\section{RESULTS AND DISCUSSION}

ASR was detected on January $25^{\text {th }}, 2018$, at GS V8, 44 days after seedling emergence, with $1.85 \%$ leaflet incidence.

Analysis of variance showed interaction between the two tested factors.

Severity in the unsprayed plots was $87 \%$ and ranged from 6.0 to $74 \%$ in plots that received fungicide. The overall means were 12 , 40 and $67 \%$ severity for 8, 12 and 16-day intervals, respectively. For $1.0,1.5,2.0,2.5$ and $3.0 \mathrm{~L} / \mathrm{ha}$, severity was $51,42,38,34$ and $33 \%$, respectively (Table 1 ).

At eight-day intervals (6 sprayings), control ranged from 75 to 93\%; at 12-day intervals (4 sprayings), it ranged from 35\% to $63 \%$, and at 16-day intervals (3 sprayings), control varied from 15 to $29 \%$. Regarding levels, the control overall mean was 42, 52, 57, 60 and $62 \%$ for $1.0,1.5,2.0,2.5$ and $3.0 \mathrm{~L} / \mathrm{ha}$, respectively. Considering the overall means, the longer the interval between applications, the lower the control level response (Table 2).

Grain yield ranged from $2,753 \mathrm{~kg} / \mathrm{ha}$ in the unsprayed plots to $4,332 \mathrm{~kg} / \mathrm{ha}$ in plots treated with six sprayings $(3.0 \mathrm{~L} / \mathrm{ha}$ and eight-day intervals). Therefore, the damage was $1,579 \mathrm{~kg} / \mathrm{ha}$ or $63.5 \%$ reduction in grain yield. In the overall mean, the yield range was 4,045, 3,696 and 3,308 kg/ha for 8, 12 and 16-day intervals, respectively. Considering levels, the yield range was $3,318,3,517,3,797,3,870$ and $3,912 \mathrm{~kg} / \mathrm{ha}$ for 1.0 to $3.0 \mathrm{~L} / \mathrm{ha}$, respectively (Table 3 ).

One of the first studies that must be done in plant pathology should be damage quantification for a given disease in a given host. As a function of the disease amount and not simply of its presence, damage must be expressed as a mathematical function of the disease amount

Table 1. Effect of treatments on leaflet rust severity (\%)

\begin{tabular}{|c|c|c|c|c|c|c|c|c|c|c|c|c|c|c|c|c|c|}
\hline \multirow{3}{*}{$\begin{array}{l}\text { Interval (Days) } \\
8\end{array}$} & \multicolumn{15}{|c|}{ Chlorothalonil level (L/ha) } & \multirow{2}{*}{\multicolumn{2}{|c|}{ Mean }} \\
\hline & \multicolumn{3}{|c|}{1.0} & \multicolumn{3}{|c|}{1.5} & \multicolumn{3}{|c|}{2.0} & \multicolumn{3}{|c|}{2.5} & \multicolumn{3}{|c|}{3.0} & & \\
\hline & A & 22 & $\mathrm{c}$ & $\mathrm{B}$ & 14 & $\mathrm{c}$ & $\mathrm{C}$ & 10 & $\mathrm{c}$ & $\mathrm{CD}$ & 8 & $\mathrm{c}$ & $\mathrm{D}$ & 6 & $\mathrm{c}$ & 12 & $\mathrm{c}$ \\
\hline 16 & A & 74 & a & $\mathrm{B}$ & 69 & a & $\mathrm{B}$ & 68 & a & $\mathrm{CD}$ & 62 & a & $\mathrm{E}$ & 62 & a & 67 & a \\
\hline Mean & $\mathrm{A}$ & 51 & & $\mathrm{~B}$ & 42 & & C & 38 & & $\mathrm{D}$ & 34 & & D & 33 & & & \\
\hline
\end{tabular}

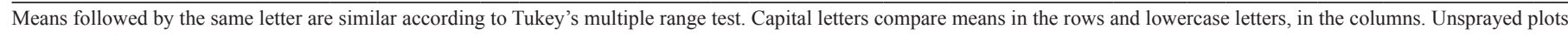
$-87 \%$ severity. 
Table 2. Effect of treatments on rust control (\%)

\begin{tabular}{|c|c|c|c|c|c|c|}
\hline \multirow{2}{*}{$\begin{array}{c}\text { Interval } \\
\text { (days) }\end{array}$} & \multicolumn{5}{|c|}{ Chlorothalonil level (L/ha) } & \multirow{2}{*}{ Mear } \\
\hline & 1.0 & 1.5 & 2.0 & 2.5 & 3.0 & \\
\hline 8 & 75 & 84 & 89 & 91 & 93 & 86 \\
\hline 12 & 35 & 50 & 59 & 61 & 63 & 54 \\
\hline 16 & 15 & 21 & 22 & 28 & 29 & 23 \\
\hline Mean & 42 & 52 & 57 & 60 & 62 & \\
\hline
\end{tabular}

Unsprayed plots - $87 \%$ severity.

Table 3. Effect of treatments on soybean grain yield $(\mathrm{kg} / \mathrm{ha})$

\begin{tabular}{|c|c|c|c|c|c|c|c|c|c|c|c|c|c|c|c|c|c|}
\hline \multirow{2}{*}{$\begin{array}{c}\text { Interval } \\
\text { (Days) }\end{array}$} & \multicolumn{15}{|c|}{ Chlorothalonil level (L/ha) } & \multirow{2}{*}{\multicolumn{2}{|c|}{ Mean }} \\
\hline & & 1.0 & & & 1.5 & & & 2.0 & & & 2.5 & & & 3.0 & & & \\
\hline 8 & $\mathrm{C}$ & 3.610 & $\mathrm{a}$ & $\mathrm{BC}$ & 3.923 & a & $\mathrm{AB}$ & 4.169 & a & $\mathrm{AB}$ & 4.191 & a & A & 4.332 & $\mathrm{a}$ & 4.045 & $\mathrm{a}$ \\
\hline 12 & $\mathrm{C}$ & 3.260 & $\mathrm{~b}$ & $\mathrm{C}$ & 3.393 & $\mathrm{~b}$ & B & 3.821 & $\mathrm{~b}$ & $\mathrm{AB}$ & 4.002 & a & $\mathrm{AB}$ & 4.002 & $b$ & 3.696 & b \\
\hline 16 & B & 3.085 & $\mathrm{~b}$ & $\mathrm{AB}$ & 3.236 & $\mathrm{~b}$ & $\mathrm{AB}$ & 3.400 & $\mathrm{c}$ & A & 3.417 & b & $A B$ & 3.403 & $\mathrm{c}$ & 3.308 & $\mathrm{c}$ \\
\hline Mean & $\mathrm{C}$ & 3.318 & & B & 3.517 & & A & 3.797 & & A & 3.870 & & A & 3.912 & & & \\
\hline
\end{tabular}

C.V. (\%)

4.45

Means followed by the same letter are similar according to Tukey's multiple range test. Capital letters compare means in the rows and lowercase letters, in the columns. Unsprayed plots $-2,753 \mathrm{~kg} / \mathrm{ha}$.

(leaflet incidence/severity) $(2,7)$.

In the present experiment, the relationship between grain yield (y) and ASR severity (x) was represented by the function $y=4,309.3$ $\mathrm{kg} / \mathrm{ha}-16.01 \%$ leaflet severity $\left(\mathrm{R}^{2}=0.8659\right)$ (Fig. 1). Function and damage are similar to those reported by Danelli et al. (2).

The regression equation, $y=13.169 x+2,966.5$ (Fig. 2), showed that for the basic yield of $2,966.5 \mathrm{~kg} / \mathrm{ha}$ (unsprayed plots), each $1 \%$ control increased $13.169 \mathrm{~kg}$ soybean $/ \mathrm{ha}$.

The economic damage threshold (EDT) can be calculated by considering the total rust control cost of $\mathrm{R} \$ 352.00 /$ ha (crop kneading by a sprayer wheels, fungicide, fuel, soybean price, and labor), using Munford \& Norton's (7) equation modified by Danelli et al. (2). Thus, cost of control - Cc, R\$352.00/ha; Soybean price - Sp, R\$ 70.00/60 or R\$ 1,166.70/ton; Damage coefficient - Dc, $16.06 \mathrm{~kg}$ or 0.016061 ton (Fig. 1 equation); Control efficacy - Ce, $75 \%$ or 0.75 (Table 2). Replacing values in the equation: Economic damage threshold (EDT) $=[\mathrm{Cc} /(\mathrm{Sp} * \mathrm{Dc})] * \mathrm{Ce} ; \mathrm{EDT}=[352.00 / \mathrm{ha} \mathrm{Cc} /(1,166.70 / \mathrm{t} * 0.016061 \mathrm{Dc})]$

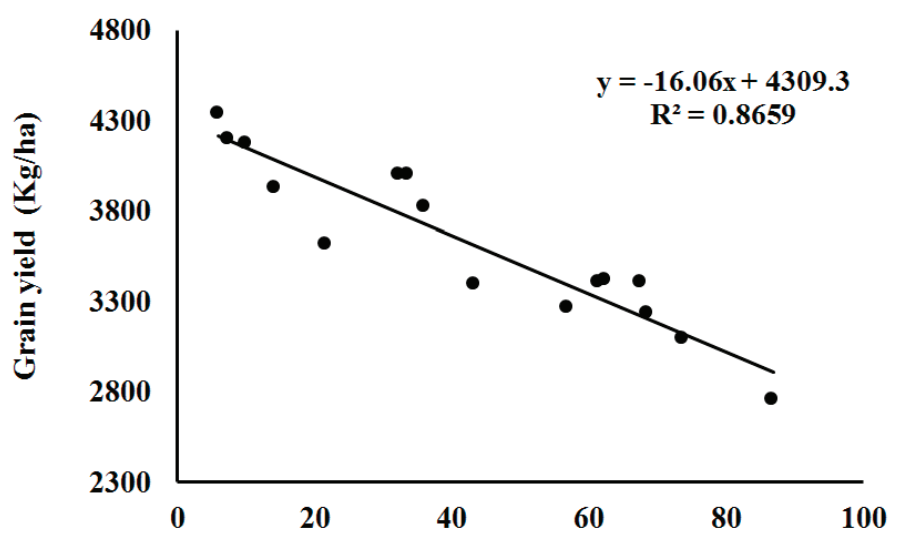

Figure 1. Relationship between soybean grain yield and Asian rust leaflet severity.

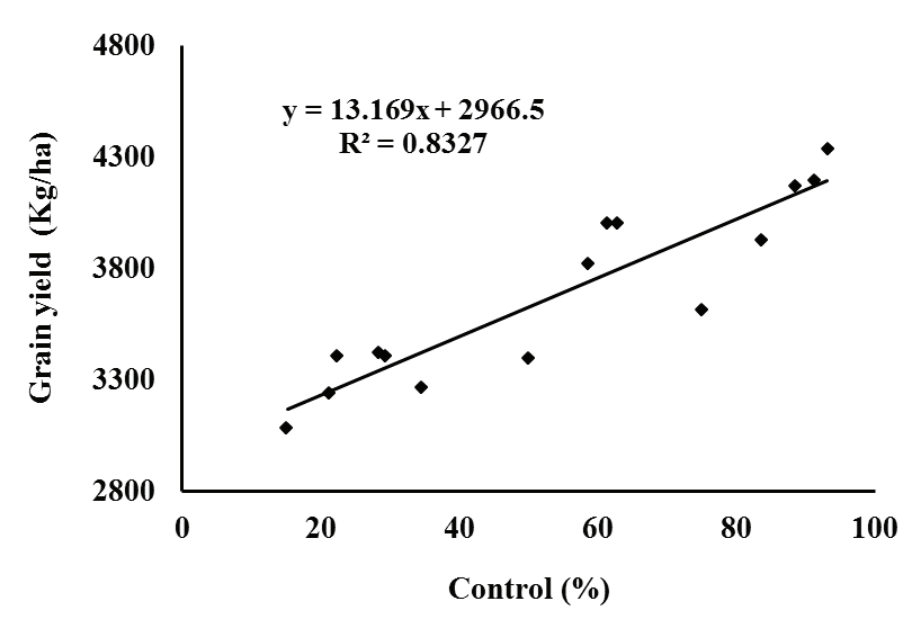

Figure 2. Relationship between soybean grain yield and Asian rust control.

$* 0.75 \mathrm{Ce}$; EDT $=[352 / 18.7383687] * 0.75=15.0 \%$ leaflet severity. Thus, for our data, EDT was $15.0 \%$ leaflet severity.

In our experiment, the control (' $\mathrm{C}$ ') efficacy required to equalize the spraying cost can be determined by considering $\mathrm{R} \$ 352.00$, or 301 $\mathrm{kg} /$ ha soybean grains; $\mathrm{C}=112.78-0.0632 * \mathrm{~d}$ (Fig. 3); $\mathrm{C}=112.78-$ $0.0632 * 301 ; \mathrm{C}=112.78-19.0232=93.7 \%$; Therefore, $\mathrm{C}=93.7 \%$ control equalizes R\$ 352.00 control cost.

ASR was detected 44 days after sowing on December $12^{\text {th }}$. This date may be too late for seeding the crop, but this happens when soybean is seeded after wheat crop harvest.

The used methodology, weekly monitoring and examination under 20-50 x magnification, allowed rust symptoms/signs to be safely detected with $<2 \%$ LI (leaflet incidence), therefore, below the EDT 


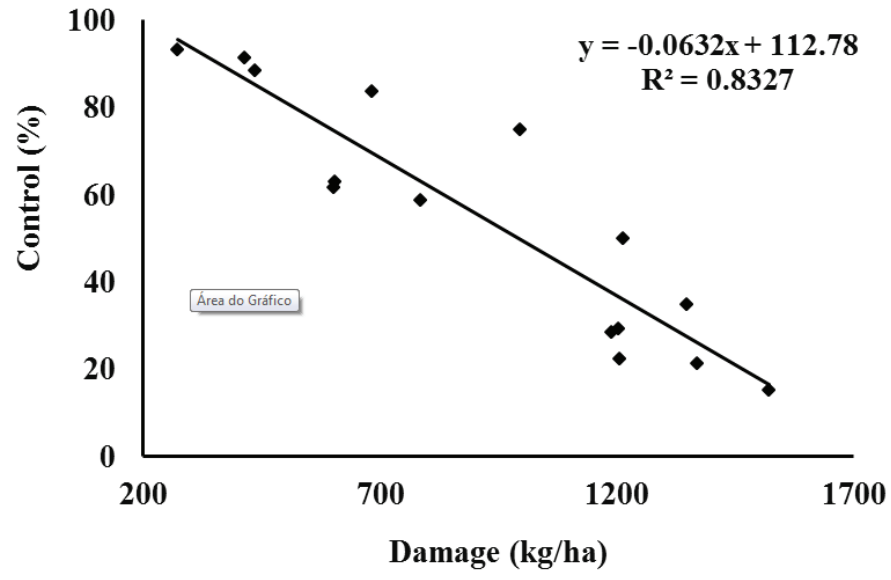

Figure 3. Relationship between Asian rust control and resulting damage to soybean crop.

of $15.0 \%$ leaflet severity.

Considering $63.5 \%$ rust damage under $87 \%$ severity in the experiment, reports of $80 \%$ damage or higher, without mentioning the methodology for its quantification, should be considered with caution.

Our data pointed out that the first application can be made before LDE is reached but should not be based on the pre-closure row spacing (4) or on a phenological stage (2). If the protection period is close to 10 days, not considering the LDE to time fungicide spraying, it may increase the number of applications which unnecessarily increase production cost, reducing the grower's profit. Our data indicate that the first application can be made before EDT ( $15 \%$ leaflet severity) is reached, but not based on empirical timing.

The interval between applications had greater positive effect on control and on grain yield, compared to levels. Chlorothalonil protection period of 14 days has been cited (8) but not confirmed for ASR control, considering that in the experimental site it rained $587.2 \mathrm{~mm}$ (normal $723.3 \mathrm{~mm}$ ) during the crop cycle.

Chlorothalonil showed potential fungitoxicity to be used in ASR control. The intervals and number of applications were used as tools to gain more knowledge about the performance of this 'new' multisite fungicide for soybean in order to fight the development of Pp resistance to the three site-specific MOA's fungicides. The best and most economic rust control should be reached by adding chlorothalonil to site-specific fungicides, which show $<50 \%$ rust control when applied alone.

\section{REFERENCES}

1. Conab. Acompanhamento da safra brasileira de grãos, Brasília, DF, v. 2 - Safra 2017/18. N. Décimo Segundo Levantamento, maio. 2018. Disponível em:http://www.conab.gov.br/OlalaCMS/uploads/arquivos/15 09 11 $10 \quad 42 \quad 03$ boletim graos maio 2018.pdf. <. Acesso em 29 de maio de 2018 .

2. Danelli, A.L.D.; Reis, E.M.; Boaretto, C. Critical-point model to estimate yield loss caused by Asian soybean rust. Summa Phytopathologica, Botucatu, v.41, n.4, p. 262-269, 2015

3. Godoy, C.V.; Koga, L.J.; Canteri, M.G. Diagrammatic scale for assessment of soybean rust severity. Fitopatologia Brasileira, Brasília, DF, v.31, p.63-68, 2006.

4. Heiffig, L.S.; Câmara, G.M.S.; Marques, L.A.; Pedroso, D.B.; Piedade, S.M. S. Fechamento e índice de área foliar da cultura da soja em diferentes arranjos espaciais. Bragantia, Campinas, v.65, n.2, p.285-295, 2006.

5. Klosowski, A.C.; Mai De Mio, L.L.; Miessner, S.; Rodrigues, R. Detection of the F129L mutation in the cytochrome $b$ in Phakopsora pachyrhizi. Pest Management Science, Oxford, v.72, n.6, p.1211-1215, 2016.

6. Morel, P.W. Roya de la soja. Capitán Miranda: Ministério de Agricultura y Ganaderia Paraguay, 2001. Comunicado Técnico - Reporte Oficial. (Série Fitopatologia, 1).

7. Munford, J.D.; Norton, G.A. Economics of decision making in pest management. Annual Review of Entomology, Palo Alto, v.29, p.157-174, 1984.

8. Pitblado, R.E. Development and implementation of TOM-CAST: a WeatherTimed Fungicide Spray Program for Field Tomatoes. Ontario: Ministry of Agriculture and Food, 1992. 19p.

9. Reis, E.M.; Reis, A.C.; Zanatta, M. Silva, L.H.C.P.; Siqueri, F.V.; Silva, J.R.C. Evolução da redução da sensibilidade de Phakopsora pachyrhizi a fungicidas e estratégia para recuperar a eficiência do controle. 3.ed. rev. e atual. Passo Fundo: Berthier, 2017. 103p.

10. Reis, E.M.; Zanatta, M.; Reis, A.C. Eficiência do controle de doenças para igualar ao custo da aplicação terrestre de fungicida - um exemplo de cálculo com a ferrugem da soja. Summa Phytopathologica, Botucatu, 2018. No prelo.

11. Silva, R.S.; Bassoi, C.R.; Foloni, J.S.S. (Eds). Informações técnicas para a trigo e triticale. Safra 2017. 10ª Reunião da Comissão Brasileira de Pesquisa de Trigo e Triticale. Londrina, PR, 27 e 28 de julho de 2016.

12. Schmitz, H.K.; Medeiros, C.A.; Craig, I.R.; Stammler, G. Sensitivity of Phakopsora pachyrhizi towards quinone-outside-inhibitors and demethylation-inhibitors, and corresponding resistance mechanisms. Pest Management Science, Oxford, n.70, v.3, p.378-88, 2014.

13. Silva, L.H.C.P.; Campos, H.D.; Silva, J.R.C.; Ribeiro, G.C.; Rocha, R.R.; Moraes, D.G. Eficácia reduzida de triazóis no controle da ferrugem asiática. Fitopatologia Brasileira, Lavras, v.33, p.228, 2008. Suplemento.

14. Simões, K.; Hawlik, A.; Rehfus, A.; Gava, F.; Stammler, G. First detection of a SDH variant with reduced SDHI sensitivity in Phakopsora pachyrhizi. Journal of Plant Diseases and Protection, Berlin, v.125, n.1, p.21-26, 2018. 